\title{
The Sense of a Never-Ending Delusion
}

Bitmeyen Bir Aldanma Duygusu

\author{
Ela İpek Gündüz
}

Gaziantep University, Turkey

\begin{abstract}
Julian Barnes in his novel The Sense of an Ending (2011) depicts an old man who is confronting some instances of his young age. In the process of remembering, he is dealing with the unreliability of his memory. This is both because of the nature of memories and some buried realities of his narrative. The film adaptation of the novel released with the same title The Sense of an Ending (2017), directed by Ritesh Batra and written by Nick Payne, represents sections from the past and the present of this man, Tony Webster, who tries to revalue his life by telling his life story. The film adaptation of the novel presents the subjective narrative of Tony through certain flashbacks, which carry significant traces of some annoying memories. The film adaptation keeps the novel's concerns about old age including some deviations within the plotline, yet it also contributes to the evaluation process of the slippery recollection of the memories that are shaping the present self of the mature individual. In this article, the film The Sense of an Ending adapted from Julian Barnes's novel that visualises the traces of a traumatic incident causing the old protagonist to re-evaluate his life will be elaborated on.
\end{abstract}

Keywords: Julian Barnes, memory, film adaptation, old age, The Sense of an Ending

Öz

Julian Barnes Bir Son Duygusu (2011) isimli romanında gençliğinin bazı olaylarıyla yüzleşen yaşlı bir adamı anlatır. $\mathrm{Bu}$ adam hatırlama sürecinde, hafızasının güvenilmezliğiyle uğraşmaktadır. Bu, hem hatıraların doğasından hem de onun kişisel hikâyesinin bazı gömülü gerçekliklerinden ötürüdür. Romanın Bir Son Duygusu (2017) olarak aynı adla gösterime giren, Ritesh Batra'nın yönetip, Nick Payne'in senaryolaştırdığı film adaptasyonu, kendi hayat hikâyesini anlatarak hayatına yeniden değer biçmeye çalışan bu Tony Webster isimli adamın geçmiş ve şu anından kesitler betimlemektedir. Romanın film adaptasyonu, Tony'nin bazı rahatsız edici hatıralardan önemli izler taşıyan sübjektif anlatısını çeșitli geriye dönüșlerle (flashback) sunar. Film adaptasyonu, romanın yaşlılık hakkındaki kaygılarını olay örgüsü çizgisinden bazı sapmalar içererek korur. Nihayet bu adaptasyon, olgun bireyin şimdiki benliğini şekillendiren hatıraların güvenilmez şekilde hatırlanmasının değerlendirme sürecine katkıda bulunur. $\mathrm{Bu}$ makalede, yaşlı başkarakterin kendi hayatını yeniden değerlendirmesine neden olan travmatik olayın izlerini görselleştiren Julian Barnes'ın romanından adapte edilmiş olan Bir Son Duygusu adlı film ayrıntılı olarak incelenecektir.

Anahtar Kelimeler: Julian Barnes, hafıza, film adaptasyonu, yaşlılık, Bir Son Duygusu

CUJHSS, December 2020; 14/2: 216-228. DOI: 10.47777/cankujhss.848893

(C) Çankaya University ISSN 1309-6761 Printed in Ankara

Submitted: June 20, 2020; Accepted: Dec 9, 2020

ORCID\#: 0000-0001-7688-8470; elaipekgunduz@hotmail.com 
Julian Barnes's novel The Sense of an Ending (2011) that deals with issues such as the passage of time, old age, giving meaning to one's own life specifically forms a narrative which is a subjective journey to a personal past. In the novel, as a theme, people's evaluation of their life when they reach their old age is questioned since it is meaningful to re-evaluate the personal position when they come to the ultimate end: death. In that sense, the limitedness of time, personal time, the constructed story of the individual, and old age including many materials about the past are the interrelated topics that Barnes discusses in his novel. Barnes traces the individual's lifelong struggle to live, forget, and remember certain instances in their lives. Barnes's novel The Sense of an Ending (2011) shares Frank Kermode's book's title The Sense of an Ending (1967) that focuses on how in several "ways we try to make sense of our lives" (Kermode 3). Barnes deals with the idea that the way you remember certain things in your life including notions that are perhaps a part of your regressions (which you want to forget) is the sum of your life, as in the case of the protagonist Tony. In the novel, Tony's newly remembered version of the repressed memories that are traumatic finally leads him to the unavoidable evaluations of his present self. Having these issues in mind, the director Ritesh Batra and the screenwriter Nick Payne produced the film adaptation The Sense of an Ending (2017) that presents certain issues reflecting the ambiguities and dilemmas of old Tony, who struggles to find a way out of these annoying memories. Yet, the film version, despite carrying the spirit of these issues involved in the novel, through editing, flashbacks, and juxtaposed mise en scènes, deviates from the original work in tracing trauma.

In the film adaptation, Barnes's novel is used as the basis and the script remains loyal to Barnes's text including some changes and digressions. The film adaptation presents Barnes's old protagonist Tony Webster who tackles his memory that leads him to make a journey to his youth. At present, Tony gets a letter from his university girlfriend Veronica's mother Sarah. She has left him money and a diary. He then learns that Veronica keeps the diary. Retrospectively, the director shows Tony's classmate Adrian Finn who speculated about a student's suicide implying that it is impossible to know the real reason for his death (which is a foreshadowing). After Tony met Veronica, and she became his girlfriend, her mother Sarah dubiously flirted with him. Veronica and Tony's relationship finished and then he received a letter from Adrian who demanded Tony's acceptance of their relationship. He had written a letter to him and he heard nothing about them afterward. Then his friends told him that Adrian had committed suicide. Through the editing of the director, the film jumps to the present, at which Tony is telling the details of these past events to his ex-wife Margaret. Then, he meets Veronica but learns that she burned the diary (which may be an explanation for Adrian's suicide). Instead, she gives him the letter that he wrote to her and Adrian. After seeing Veronica with a disabled man whose name is Adrian, Tony learns that this young Adrian is Veronica's brother (whom he assumes to be the son of Adrian and Veronica). At the end of the film, Tony apologises to Veronica in a letter for his past deeds and continues his life. 
Barnes's novel focuses on old age evaluations of life by tracing certain memories evoked by an inheritance issue leading Tony to remember and reposition specific past events that are traumatic. It is interesting to see how the film adaptation represents that subjective voyage of Tony in his handling the lost reality. In the novel, like a lacework, Barnes knits issues such as time, life, death, memory, accumulation, remorse, and responsibility. In the film, the juxtaposition of past and present as an editing tool reinforces the idea that a traumatic past may disturb the individual and without a "sense of an ending," it is impossible for the mature individual to continue his life. How the novel and the film present these issues is different. The novel has two chapters: the first chapter focuses on Tony's past and the second chapter mainly presents old Tony re-evaluating his past, whereas the film intertwines the past and the present, especially by using the present situation of Tony as the frame narrative. In this way, the film's plot revolves around the ideas, speculations, and deductions of Tony that lead the audience to follow the personal story of the protagonist that includes delusive traces of his memory. In this article, the film adaptation of Barnes's novel will be analysed for its handling of Barnes's notions presented in his novel faithfully and its presenting memory and traumatic incidents related to old age by paving the way to capture the aura of the original text. In the film, it is intriguing to see how the visualised scenes will follow the traces of the subjective memories of Tony in different versions.

In the novel, the plot begins with some fragments from Tony's past: "- a shiny inner wrist; steam rising from a wet sink as a hot frying pan is laughingly tossed into it; ... - bathwater long gone cold behind a locked door. This last isn't something I actually saw, but what you end up remembering isn't always the same as what you have witnessed" (Barnes, The Sense 3). Even at the beginning of the novel, the narrator emphasises the unreliability of his memory path and his narration. In contrast, the film starts with the voice-over of Tony asserting that he "feel[s] no special nostalgia for [his] school days" (The Sense 00:50$00: 55)$. The voice-over of old Tony comments about the shots that are showing young Tony. The remembered memories begin with a long shot mise en scene; male students are shown at school and then, Tony in the middle with the medium shot is shown. Tony as the narrator utters that his sole aim is not specifically remembering this period of his past. Still, he explains youthfulness as including the notions of being inexperienced and unknowing about the future consequences of life:

In those days we imagined ourselves as being in a holding pen, waiting to be released into our lives. And when that moment would come, we would be at university. How were we to know that our lives had already begun, and our release would only be into a larger holding pen? And in time, a larger holding pen. (The Sense 01:09-01:42)

Tony begins the story by asking questions about people's being the writers of their life narratives as expressed in the novel. The film adaptation, in the beginning, situates the audience to follow Tony's reminiscences about the younger Tony with a mature perspective. By using the voice over of old Tony, 
the spectators have a chance to follow his life story retrospectively. Likewise, after speculating about the passage of time, Barnes's narrator signifies the importance of certain events related to his school days and he focuses on these memories in the first chapter.

The scenes about young Tony and Veronica at a university party depicted with yellow colours present Tony with a medium shot with his back passing a tunnel-like corridor in the party. After passing the door, facing the camera, looking at Veronica, we hear the voice-over of the mature Tony who speculates about the younger Tony: "When you are young you want your emotions to be like the ones that you read about in books. You want them to overturn your life and to create a new reality but there is a second hand insisting on speeding up and time delivers us all took middle age and old age and you want something milder. Don't you?" (The Sense 01:48-02:11). With this question, the film is divided into two in presenting mise en scènes: with warm colours/ lights and music reminding one of the 60s, his school days are shown as times of joy, and hopeful instances; with cold colours/ lights and silences, his present ordinariness is shown. Mostly in these shots, there is no excitement, surprise, and expectancy; instead, the monotony of life continues for Tony. In these mise en scènes, we see old Tony mostly alone in his ordinary life, whereas, he is accompanied in his memories. As a digression, there is a camera shop in the film. His relation to cameras is shown in the shot with Veronica in which she is dealing with a camera so this place as a setting may indicate Tony's buried feelings about Veronica. These daily routines of Tony and the position of his daughter Susie are different in the film and some details about his family in his past are told only in the novel. Yet, the main issues about remembering one's past are the same.

Both in the novel and the film, some gaps including some misperceptions about feelings among Tony, his ex-wife Margaret and Susie are hinted at. Once he can reach the source of his trauma and name it, Tony finds a reconciliation within his relationship with Margaret and Susie as well. When he gets a letter from Sarah Ford, which is about her inheritance of some money to Tony, and an attached document which is a diary (soon revealed to be Adrian's diary), Tony immediately remembers Sarah putting a burning pan into the washbasin and his feelings accompanying this specific moment are remembered. ${ }^{1}$ While this issue of two documents (including the missed diary) prepossesses his mind, the first important present part that helps him to remember the details of the chain of memories starts. In the film, Tony's remembrances are not established when he is alone; instead, when he is with his wife and telling her about the details of these past incidents, he delves into memory. These conversations with his ex-wife Margaret and then, his efforts to find people who have

\footnotetext{
1 As Tony reimagines "a specific episode from his own life story, he reflects on the deceitfulness of memory driven by human beings' need to go on with their lives despite having gone through negative episodes. However, as memory is revisited and revised in his last life stage, the protagonist also rediscovers a remorse that was hidden deep inside himself and that he had managed to ignore by modifying what he remembered from that episode of his life" (Piqueras 89).
} 
experienced those events together with him maintain a frame for the audience to follow the memories.

Some recurring moments are shown as significant mise en scènes in the film. Tony's having lunch with Margaret to tell her about the inheritance issue (Margaret and Tony are situated in different shots alone signifying their separation) starts this flow of memories. The university party including the first sight of Veronica who deals with a camera, the bridge where Tony and Veronica are together (but not presented in the same shots), the watch positioned inside of his wrist, their flirtation without sexual intercourse in the car, Veronica's playing with Tony's fingers are shown via the editing of the director. These past instances are depicted with warm colours signifying the youth of the characters and reflecting the style of the 60s and the present time shot with cold colours reinforcing the detachment of Tony to his own emotions. The joyful atmosphere is maintained by the music used in these scenes as well. The names of the songs are "There Was a Time," "Time Has Told Me" and "Time is on My Side," etc. helping both to create the soul of 60s energy and used as reminders of the significance of "time." Margaret's questions lead Tony to remember these scenes but it is evoked that something is disturbing him about Veronica and the memories related to her. Even Margaret realises that there is something mysterious about these reminiscences, and tells Tony both in the novel and the film, "Tony, you're on your own now" (Barnes, The Sense 106).

When the film passes to the scenes of the "humiliating weekend" (Barnes, The Sense 63) for Tony at Veronica's family's house with her father, brother Jack and her mysterious mother, the source of his traumatic recollection of certain events begin to be revealed. In the novel, Tony asserts about memory: “... my memory has increasingly become a mechanism which reiterates truthful data with little variation. I stared into the past, I waited, I tried to trick my memory into a different course. But it was no good" (Barnes, The Sense 64). Tony fails to understand the reason for Sarah's leaving him these documents since he remembers only Veronica's coldness, the father and brother's mocking him and the mother's intriguingly being interested in him by warning him: "Don't let Veronica get away with too much" (Barnes, The Sense 28). These words of the mother used in the novel and the film indicate that there is something weird about the weekend. When Tony begins associating these memories one by one, Tony and Sarah's dialogue about poets, the burning pan, Sarah's warning him about Veronica, her flirtatious behaviours, Veronica's coldness, and the horizontal gesture of Sarah, ${ }^{2}$ the memories continue to disturb him more as haunting figures. Even at one instant, he imagines Sarah on the escalator at the present time.

\footnotetext{
2 "This picture is symbolic in that it looks more like a young girl seeing off her lover than a mother her daughter's. This illusion is intensified by the next detail ... This specific gesture reinforces the 'young girl' illusion, resulting in a vivid image of a middle-age woman trapped in a desperate marriage pining for the romantic love and freedom she had been denied" (Wenquan 93).
} 
Tony's encounter with these details of an annoying period of his life with a mature vision is significant since in old age, some of the trivial and significant past issues may be forgotten, but some of the faded memories revalue their present existence. By daring to face the past realities, choices, and mistakes, the mature individual may reach a state of completion/ reconciliation with his younger self: "Researchers who focus on the personal past generally embrace a view of adulthood, particularly late life, as a rich phase for remembering and re-evaluating one's personal past" (Bluck, Alea and Ali 290). Likewise, Tony encounters his buried memories and secrets of his past life. As Henry Krystal asserts: "In old age ... we come to the point where our past lies unfolded before us, and the question is, what should be done with it? The answer is that it must be accepted or one must keep waging an internal war against the ghosts of one's past" (78). In both the novel and the film, Tony struggles in accepting or rejecting some aspects of his younger self. This personal journey is a promising source for the film adaptation of Barnes's novel since the deviations of a normal mind in its struggling to reach the authentic version are traced via the sequential scenes. As the screenwriter, Nick Payne asserts, "I think the bit that really appealed was that it was about memory but not in a way that film normally is; in a sort of, someone with a memory disorder or someone with amnesia. It is a really everyday kind of memory". ${ }^{3}$

Tony remembers the uniqueness of these events when he meets Margaret a second time at her house and this time, he dares to encounter the harsh realities. He revisits those instances, and each time, he remembers more details. When he remembers more details, he begins feeling the density of the awareness of the remoteness of his young age. At the beginning of the film, only a larger prospection of the school full of young boys is shown, whereas when he remembers it for a second time, he re-imagines his classroom and Adrian who speculates about both personal and public history: "We may never find the truth!" (The Sense 42:10-42:12) and "History is the certainty in Dawson's suicide" (The Sense 42:19-42:22). He remembers Adrian with these utterances of him about a fictionalised past. What Tony mostly remembers is his friend Adrian's committing suicide at his bathtub, Adrian's ideas about death, seeing Veronica at a party with a photo machine, and having sexual frustrations both with Veronica and then with her mother. Even in one instance, he revisits this party scene as the old Tony. He gazes at Veronica in the past. In this way, the spectators are prepared to witness Tony's mature senses inserted into his memories. Yet, these scenes also evoke a sense of turbidity because it is a painful process for Tony to confront both realities and to cope with time. Batra interweaves one shot after another respectively from present to past and achieves both to show Tony's memory path and to reveal his senses ascribed to them. When Tony becomes involved more in these memories, both he and the spectators realise that these interrelated events disturbing him may be called traumatic instances. As Judith Herman explains:

\footnotetext{
3 "Nick Payne: The Sense of an Ending." Youtube, uploaded by The Movie Times. 4 March 2017, www.youtube.com/watch?v=bypVZ9C67oU. Accessed 1 November 2020.
} 
"The conflict between the will to deny horrible events and the will to proclaim them aloud is the central dialectic of psychological trauma" (1). Tony experiences this dilemma while he is telling these events to Margaret in the film.

As it is followed in the film, the associated reminiscences about Veronica, Sarah and Adrian form a traumatic instance on Tony's mind. By telling the renewed version of his life story, these instances lead Tony's mind to reveal the source of his trauma. Although there are different explanations about trauma (even in Sigmund Freud's theory), Freud describes it as, "any excitations from outside which are powerful enough to break through the protective shield. It seems to me that the concept of trauma necessarily implies a connection of this kind with a breach in an otherwise efficacious barrier against stimuli" (Freud 23). All these interrelated past events affect Tony's "shield," and he begins remembering a significant reality that he forgets. Margaret's questions about Veronica and her comments about Veronica implying that she is Tony's first love lead Tony to realise some of his own buried realities even not confessed to himself. Both he and the audience become shocked in noticing the truth and the significance level of certain people and events in his life. As Cathy Caruth introduces the arguments about trauma:

Psychic trauma involves intense personal suffering, but it also involves the recognition of realities ... To cure oneself - whether by drugs or the telling of one's story or both - seems to many [people] to imply the giving-up of an important reality, or the dilution of a special truth ... [For Freud] the possibility of integrating the lost event into a series of associative memories, as part of the cure, was seen precisely as a way to permit the event to be forgotten. (vii)

Barnes's protagonist Tony, both in the novel and the film, needs to tell his life story to himself, to the others, (especially in the film) to his wife Margaret because of the need to secure his present self which is the outcome of his assumed past. Yet, when he finds out the possibility of a forgotten version, he begins recalling the associative memories. Barnes in his book Nothing to Be Frightened of (2008) emphasises the notions of remembering and giving meaning to one's own life: "Adulthood brings approximation, fluidity and doubt; and we keep the doubt at bay by retelling that familiar story, with pauses and periods of calculated effect, pretending that the solidity of narrative is a proof of truth" (37). Old Tony's narrative that includes "pauses" and "periods of calculated effect" paves the way to the audience to witness the delusiveness of the memories. Yet, he is still willing to reposition these gaps in his life. As Zekiye Antakyalığlu explains: "Tony is conscious of the imaginative and subjective aspect of memories" and "he needs the corroboration of a witness for the truth value of his version of the past. He decides to get in touch with Veronica who might help him find answers to his questions" (329).

At first by telling his past to Margaret, Tony tries to capture the past, and then he is in search of a real witness to understand the enigma behind Sarah's will, Veronica's feelings, Adrian's suicide. Although Tony is in search of a witness to 
prove his reminiscences as the true versions, Veronica mostly does not contribute to his present evaluations since her remembrance about the reality is very different from Tony's version. When he meets old Veronica at the bridge, they do not exist in the same shot which indicates their distance. In the cafe scene, for instance, Tony is on the left and Veronica on the right side of the shot and we see them from their profile, and the crowd's noise interrupts them. She is very cold and distanced; the setting is also devised in cold lights. At first, it is indicated that Veronica is an aloof woman. We see his back, her back, she leaves, and there are loneliness and silence for Tony once more. By following the traces of his memory path, certain "associative" memories lead Tony to change, even delete the real event he experienced. Yet, "the versions of the same story" (vii) lead Tony to the difficulty of the process of remembering the traumatic past. In the novel, the narrator explains this as:

[T] he brain doesn't like being typecast. Just when you think everything is a matter of decrease, of subtraction and division, your brain, your memory may surprise you. As if it's saying: Don't imagine you can rely on some comforting process of gradual decline - life's much more complicated than that. (Barnes, The Sense 112)

In one way or another, while remembering the lost but real event throughout the traumatic suffering, these different versions continue to disturb the subject and this distortion is painful.

Tony's suffering from some interrelated past events - the graduation scene, Veronica at the party, Veronica's mother waving him, Adrian's death, etc. - are repeatedly represented in the film. Especially after Veronica handles the harsh letter that Tony has sent to Adrian and Veronica, he explicitly remembers the real version. As M. Horowitz explains: "Years after its creation it remains unassimilated, a self-renewing presence, perpetually relieving the moment of its origin" (Horowitz 1976). ${ }^{4}$ Every time Tony repeatedly remembers certain instances, he loses his path in reaching reality: "The traumatic reexperiencing of the event thus carries with it ... the 'collapse of witnessing,' the impossibility of knowing that first constituted it. And by carrying that impossibility of knowing out of the empirical event itself, trauma opens up and challenges us to a new kind of listening, the witnessing, precisely, of impossibility" (Caruth 10). In other words, old Tony remembering his traumatic memories is crucial since this new attempt is just another version, a new kind of reshaping and representing those events that will be witnessed by both Tony and the spectators. This version that includes Tony's present deductions will not correspond to the exact reality. Yet, as a different work, the film sometimes fails to correspond to the enigmatic structure of the novel.

I know this much: that there is objective time, but also subjective time, the kind that you wear on the side of your wrist, next to where the

\footnotetext{
4 "Ordinary memories fade and belong to the past. They are eventually confused and conflated with other ordinary memories and assimilated into webs of remembrance. When they penetrate into the present, it is as nostalgia, regret, and a desire for things new gone" (Horowitz 1976).
} 
pulse lies. And this personal time, which is the true time, is your relationship to memory. So when this strange thing happened - when these new memories suddenly came upon me - it was as if, for that moment, time had been placed in reverse. As if for that moment, the river ran upstream. (Barnes, The Sense 122)

As Tony explains in the novel, after these realisations of his darker side when he was young, Tony loses himself in his subjective time. At that point, the audience has questions in their minds about the innocence of Veronica. Tony, after meeting with his school friends and speculating about Adrian's death, is once more entrapped in his memory which reminds him of Adrian's suicide after his cruel letter including the bad implications about love, sexuality, pregnancy, and suicide which are directly parallel to their friend Robson's death. In the novel, Tony names his feelings as "remorse" (Barnes, The Sense 99); in the film, he shows these emotions while he is talking to Susie at the hospital.

As Erik Erikson explains, to reach a sense of reconciliation with the outcomes of life, the mature person should accept his "own life cycle and ... the people who have become significant to it as something that had to be, and that, by necessity, it accepted no substitutions" (98). In the film, both the life cycle and the versions of the past reminiscences are depicted vividly sometimes through the relations of the characters, sometimes through their behaviours. As Adrian quotes from Patrick Lagrange both in the novel and the film "History is the certainty produced at the point when the imperfections of memory meet the inadequacies of documentation" (The Sense 41:28-41:34). Tony's tracing the reminiscences of his memories of Veronica is doomed to his confrontation with the gaps. This point of realisation of the authentic past is revealed after Veronica's refusal of giving him Adrian's diary, which is a historical document. Although Tony thinks that he sends an approval letter to Veronica and Adrian, actually he has sent an awful letter in which he was accusing and blaming them. That is why, when Tony realises that he has believed a lie that he has devised all through his life, all his safe construction of life falls on him. When Adrian's tutor told him in the pub that Veronica is young Adrian's sister, even his present/mature comments about Veronica and Adrian turn out to be a fallacy. As a result, Tony learns the fact that he should pay attention to the present reality more so as not to misinterpret his life once again.

Positioned as an insignificant event in distant parts of his memory, Tony did not think that his affair with Veronica, her relation with Adrian, or her mother was crucial as when later he realises them to be. When he is confronted with Sarah's letter at the age of sixty-five, he is awakened both to see how an insignificant issue would change his sense of his own life and how all these events and people are interrelated to each other. This is because of the belatedness of the traumatic past event (as in the case of the memories ${ }^{5}$ ). As

5 "There is no perception which is not full of memories" (Bergson 33). When individuals try to make sense out of their lives, their present information and feeling inherently include the traces of experiences because in giving meaning to life, it is impossible to distinguish the 
Cathy Caruth asserts, there exists an enigmatic essence of the historical past and this is paradoxical. It is an interesting fact that while a person remembers his/her trauma, even though other people are involved in that specific incident (as in the case of Tony), the subject who repositions that event is the one who should be dealing, evaluating, and naming the source of the traumatic event. Caruth exemplifies this idea concerning the concept of "witnessing": "the inability fully to witness the event as it occurs, or the ability to witness the event fully only at the cost of witnessing oneself" (7). This notion of witnessing the authentic event is not only related to the other people involved in that event but also the subject himself who should be eager and daring to witness the real reality about the source of his traumatic past. The contribution of this act of revisiting this special instance of his past is now he will be able to identify himself through his memory, which redirects his sensation about his life related to the passage of time.

In the end, Tony asks, "How often do we tell our life story? It is just a story we are told about our lives, a story about our lives told to others" (while spreading his photos from the bridge), he utters, "but mainly to ourselves" (The Sense 01:41:11-01:41:34). Tony concludes that despite certain regressions about memories of his life, these memories are the unavoidable consequences of his identity. Tony by remembering this specific instance in his life with a new corrected version of it, changes his mature attitude to confront his reality but by still accepting the fact that our life is mostly deciphered as a devised story of our projection. As Barnes asserts: "We spend our lives only partially seeing ourselves and others, and being partially seen by them in return ... But still, we long for the comfort, and the truth, of being fully seen. That would make for a good ending, wouldn't it?" (Barnes, Nothing 194).

In this period of his life, due to his maturity, Tony comes to terms with the love affair of his girlfriend Veronica and his best friend Adrian that was the source of his trauma. "Traumatic memory differs from ordinary memory insofar as it is timeless and unintegrated, which causes victims to remain embedded in the trauma as a contemporary experience instead of being able to accept it as something belonging to the past" (Young 56). That is why in the film all these past events are positioned within Tony's present relations with his ex-wife and daughter. He both has some misunderstandings within his present and past relations. One of the deviations of the film about Susie's life such as having a baby with the company of her father Tony and the last scene including her visit with the baby to her father's camera shop indicate positive signs devised for the rest of Tony's life. These are reached only after Tony's internal feud.

I've been turning over in my mind the question of nostalgia, and whether I suffer from it. I suppose I am nostalgic. I think of my time with Margaret and Susie's birth and her first years. A bunch of kids in

present feeling from its memory. If each moment inevitably includes instances of memories, it always already has a notion of "belatedness." This belatedness is necessary for the subject to evaluate the past incident: "the examination of belatedness has a symptomatic value: not as a sign of the ... arbitrariness, but of what expresses it in order to conceal it" (Susen 79). 
school. A girl dancing for once in her life. A secret horizontal gesture beneath a sunlit Wisteria. I think of Adrian's definition of history. I think of everything that has happened in my life, and how little I have allowed to happen. I, who neither won nor lost. Who avoided being hurt and called it a capacity for survival? I think of how our lives got entwined and went along togetherfor a time. And when I look back, now, on that time, however brief, I am moved more than I thought possible. Indeed, I'm sorry that I have known nothing of your life in the years since. No doubt you could have taught this old fool a thing or two. Perhaps, in a way, you have. (The Sense 01:42:27-01:44:02)

Tony, in the end, understands that there is no way out: he will continue living, waiting for the end to come, he will be lonely, and he will have mistakes. Yet, after confronting with the traumatic incident about his younger self, he reaches a consensus between young Tony and old Tony. These two Tonies in his inner world, for sure, will continue to question the meaning of life and death and the passage of time. In the novel, for Frederick Holmes, after facing the shock of his bad side "the structure of his autobiographical narrative" changes: "The individual parts of the story are no longer concordant in relation to the end he imagined. The new perspective on his past behaviour requires a new ending" (35). Thus, the sense of his ending is questioned. At the end of the film, Tony finds a way out to reach a consensus with his past and the present self. However, the end of the novel is quite pessimistic. "There is accumulation. There is responsibility. And beyond these, there is unrest. There is great unrest" (Barnes, The Sense 150).

Barnes's novel is multi-layered and very deep in its concerns of the passage of time, a person's evaluations of the meanings of life and death in old age by creating stories. There is this notion of "accumulation"; for instance, Tony speculates about it in the novel: "Your winnings accumulate. But do your losses? ... But in life? ... Life isn't just addition and subtraction. There's also the accumulation, the multiplication, of loss, of failure" (Barnes, The Sense 103-4). Some details about Tony's family at that time, some differences about Susie, and some ideas of Tony are not used in the film. These deviations are necessary for the adaptations as Barnes also expresses in an interview about the film: "Part of my mind is running through the notion that actually, I didn't write that. Then I told myself to cheer up because it shouldn't be my book. It shouldn't be entirely my book. It shouldn't be loyal. The best way of being loyal for the filmmaker is being disloyal of the book." 6 Despite the structural differences between the novel and the film, the film adaptation maintains fidelity to some extent by preserving the significant questions that Barnes raises in his novel. The tricky aspect of subjective memory traced by the different embodiments, recurring scenes, juxtaposition of the past and the present, and the deviations complement the gaps of the novel that Barnes consciously creates. When being asked about the "enigma" of the novel, the director Batra explains,

6 "Julian Barnes: The Sense of an Ending." Youtube, uploaded by The Movie Times. 4 March 2017, www.youtube.com/watch?v=9avPtAAhJc8. Accessed 1 November 2020. 
[w]hen I picked up the book, which I loved, one of the first things I thought, regarding its ambiguities, is how much between the lines ... I was really conscious about preserving that ambiguity ... But I don't want to say that ambiguity is my forte. We live in an age when people are seeing everything. They don't want to feel things. They want to see things. When you're directing or writing something, or even editing it editing is like rewriting - you've got to be very conscious about 'What do I want people to feel here?' Not 'What do I want people to see?'7

Batra with his editing maintains the gaps that include bad memories and depicts the struggles of Tony's present mature self to complete his life story.

The contribution of the film adaptation of Barnes's novel is to help the spectators to visualise the abstract notions of memory, to trace the hidden realities (which may still be elusive and untrue) by the director's explicitly presenting some of the enigmatic sensations evoked by Barnes's novel, and to think about the meaning of telling the stories of the human beings' trivial lives. Through the juxtaposition of the selected moments belonging to Tony's past presented as flashbacks, the plot of the film reinforces both the idea of the belatedness of traumatic instances and the individual's witnessing his true self. In this way, the film adaptation complements the novel in depicting the subjective evaluations of an old man's narrative full of memories that raise questions about life, past, old age, and death. Barnes's old protagonist who has a "sense of an ending" is portrayed in his struggle to find a compromise with his younger self. The effects of certain people surrounding his past and present stories are so strong that he has to find a different way, which should be more insightful to understand both his self and the others.

\section{Works Cited}

Antakyalığlu, Zekiye. "The Sense of an Ending: Frank Kermode and Julian Barnes." English Studies: New Perspectives, edited by Mehmet Ali Çelikel and Baysar Tanıyan, Cambridge Scholars Publishing, 2015, pp. 327-335.

Barnes, Julian. Nothing to be Frightened of. Random House, 2008.

---. The Sense of an Ending. Vintage, 2011.

Bergson, Henri. Matter and Memory. Translated by N. Margaret Paul and W. Scott Palmer, George Allen and Unwin, 1911.

Bluck, Susan, et al. "Remembering the Historical Roots of Remembering the Personal Past." Applied Cognitive Psychology, vol. 28, no. 3, 2014, pp. 290-300.

Caruth, Cathy, editor. Trauma: Explorations in Memory. The John Hopkins University Press, 1995.

Erikson, Erik. Psychological Issues. vol. 1. IUP., 1959.

Freud, Sigmund. Beyond the Pleasure Principle (1920). Translated by James Strachey, edited by Jim Miller, Dover Publications, 2015.

\footnotetext{
7 O'Sullivan, Michael. "'British Reserve is Endearing': Ritesh Batra interview on 'The Sense of an Ending."' 12 Mar. 2017. www.washingtonpost.com/lifestyle/style/ritesh-batra-directorof-the-sense-of-an-ending-on-graduating. Accessed 10 Nov. 2020.
} 
Herman, Judith. Trauma and Recovery: The Aftermath of Violence - from Domestic Abuse to Political Terror. Basic, 1997.

Holmes, Frederick M. "Divided Narratives, Unreliable Narrators, and the Sense of an Ending: Julian Barnes, Frank Kermode, and Ford Madox Ford." Papers on Language and Literature, vol. 51, no. 1, 2015, pp. 27-50.

Horowitz, M. Stress Response Syndromes. Jason Aronson, 1976.

Kermode, Frank. The Sense of an Ending: Studies in the Theory of Fiction with a New Epilogue. Oxford University Press, 2000.

Krystal, Henry. "Trauma and Aging: A Thirty-Year Follow-Up." Trauma: Exploration in Memory, edited by Cathy Caruth, The John Hopkins University Press, 1995, pp. 76-99.

Piqueras, Maricel 0. "Memory Revisited in Julian Barnes's The Sense of an Ending." Coolabah, no. 13, 2014, pp. 87-95.

Susen, Simon, and Bryan S. Turner. The Legacy of Pierre Bourdieu: Critical Essays. Anthem Press, 2011.

The Sense of an Ending. Directed by Ritesh Batra, CBS Films, Lionsgate, and Studio Canal, 2017.

Wenquan, Wu. "On the Motif of Death in Julian Barnes's The Sense of an Ending." Canadian Social Science, vol. 11, no. 3, 2015, pp. 87-95.

Young, Marna. Exploring the Meaning of Trauma in the South African Police Service. 2004. University of Pretoria, PhD dissertation. 